\title{
IYD
}

http://jyd. pitt. edu/ | Vol. 14 Issue 1 DOI 10.5195/jyd.2019.596 | ISSN 2325-4017 (online)

\section{Civic Engagement Among Youth Exposed to Community Violence: Directions for Research and Practice}

\section{Sonia Jain}

DNA Global, LLC

sjain@datainaction.org

\begin{abstract}
Alison K. Cohen
University of San Francisco School of Management, Department of Public and Nonprofit Administration akcohen@usfca.edu
\end{abstract}

\section{Kei Kawashima-Ginsberg}

Center for Information \& Research on Civic Learning and Engagement, Tufts University

kei.kawashima_ginsberg@tufts.edu

\section{Catherine d. P. Duarte}

University of California, Berkeley School of Public Health, Division of Epidemiology

catherine_duarte@berkeley.edu

\section{Alexander Pope}

Department of Secondary and Physical Education, Salisbury University

axpope@salisbury.edu

\section{Abstract}

Historically and contemporarily marginalized youth who are disproportionately exposed to community violence are often the same youth who are less likely to be civically engaged. However, the community violence and civic engagement literatures have not yet fully explored how these experiences may be linked in young people's lives and in relation to what other forces. Using developmental assets and ecological-transactional frameworks, we review the emerging literature on civic engagement among youth exposed to community violence and how external developmental assets and neighborhood collective efficacy may create opportunity for their increased civic engagement. We present numerous conceptually-and empirically-based hypotheses to further examine the intersections between exposure to community violence and youth civic engagement. Ultimately, we identify opportunities for intervention.

(c) $\mathbf{E Y}$ New articles in this journal are licensed under a Creative Commons Attribution 4.0 License. This journal is published by the University Library System, University of Pittsburgh and is cosponsored by the University of Pittsburgh Press. The Journal of Youth Development is the official peer-reviewed publication of the National Association of Extension 4-H Agents and the National AfterSchool Association. 
Key words: assets-based, civic engagement, community violence, resilience, urban youth, youth development

This literature review explores if and how youth civic engagement experiences vary by exposure to community violence (ETV), and suggest future directions for research and practice. We begin by justifying why this work is warranted, providing examples of violence exposures that youth experience, and describing the development of civic engagement across adolescence and into adulthood. We then review theoretical and empirical evidence that demonstrates how civic engagement can be part of resilience expressed by violence-exposed youth and be leveraged in youth-led actions to mitigate that violence. We follow by reviewing the literature on inequalities in civic engagement and exposure to community violence, documenting how structurally marginalized young people are often both less civically engaged and more exposed to community violence. We proceed to explore possible interventions that can support civic engagement among youth exposed to violence. We conclude by offering recommendations for future research and implications for policy and practice to enhance opportunities for civic engagement among youth exposed to community violence.

\section{Defining Community Violence and Civic Engagement}

We draw from Krug, Mercy, Dahlberg, and Zwi's (2002) concept of collective violence and define community violence as the presence, in a social context, of the use of power or physical force against individuals or groups in a way that causes or could cause harm. And we conceptualize civic engagement as multi-dimensional, encompassing traditional duty-oriented forms of engagement such as voting, as well as direct engagement (i.e., participatory politics), where individuals and small groups take action of their own accord (Pope, Cohen, \& Duarte, 2018). These definitions highlight important similarities between community violence and civic engagement: they are systemic, group-level concepts created through multiple, pervasive, individual actions, and the collective impact of individual actions can affect both individual experiences and social movements. Using these definitions, we next explore how community violence and civic engagement can interrelate. 


\section{Rationale for Considering Links Between Youth Exposure to Violence and Civic Engagement}

Recent movements shaping national conversations suggest that exposure to community violence can stir both traditional and direct engagement forms of civic engagement. For example, since 2013, the Black Lives Matter movement, focused on disproportionalities in exposure to police violence among structurally marginalized populations, has been led and supported by youth committed to the power of participatory politics (Black Lives Matter, 2018; Kahne, Hodgin, \& Eidman-Aadahl, 2016). Similarly, the \#MeToo movement has leveraged the functionality and reach of social media to focus attention on the pervasiveness of sexual violence. But are these illustrations indicative of more general phenomena, particularly among youth?

Exposure to community violence and low civic engagement co-exist for many youth and are often compounded by socioeconomic disadvantage. Many have documented growing cumulative disadvantage and community violence in cities (Friedson \& Sharkey, 2015; Johnson \& Kane, 2018; Zimmerman \& Messner, 2013). Meanwhile, others have studied the experiences of structurally marginalized urban youth, finding they are less likely to be civically engaged, but that those who do engage benefit more than their structurally supported peers (McBride, Sherradon, \& Pritzker, 2006; Spring, Dietz, \& Grimm, 2007). At the intersection of these two strands of inquiry, we highlight the importance of considering civic engagement among youth living in structurally marginalized communities with higher incidences of violence. Civic engagement may serve as a coping mechanism youth of color (and perhaps other marginalized youth) use as they navigate contexts of inequality (Hope \& Spencer, 2017). Since civic engagement among youth of color in urban areas with concentrated violence was associated with reports of better mental health and well-being (Ginwright, 2010), we posit that civic engagement could help youth cope with disproportionate exposures to community violence.

Though we are primarily focused on research and programming in the United States, this may also be relevant for building resilience and civic engagement among youth living in conflictstricken regions around the world. Limited research from post-conflict countries suggests that having violence-exposed youth participate in structured civic opportunities may decrease individual- and community-level violence (Colletta \& Cullen, 2000).

Little is known about links between exposure to violence and civic engagement, including for urban youth. Urban youth can be exposed to many risk factors, of which ETV may be 
Civic Engagement Among Violence-Exposed Youth

particularly influential. While all youth have the right to political participation (Ruck, Keating, Saewyc, Earls, \& Ben-Arieh, 2016), most civic organizations do not specifically work with violence-exposed youth, which may be a lost opportunity. Further, violence-exposed youth may be more motivated to volunteer (Spring et al., 2007) and take part in social movements like Black Lives Matter (Dohrn \& Ayers, 2016); if they are civically engaged, they could promote social capital and curb violence in their community (Kennedy, 2007; Sampson, McAdam, MacIndoe, \& Weffer, 2005).

\section{Youth Exposed to Community Violence and Polyvictims}

American youth living in urban settings are disproportionately exposed to high rates of community violence compared to youth elsewhere (Wade, Shea, Rubin, \& Wood, 2014), with implications for positive developmental outcomes (Jones, 2014). Urban youth are also disproportionately exposed to interpersonal (e.g., physical assault or abuse, sexual assault or abuse, caregiver maltreatment, conventional crime) (Finkelhor, Turner, Shattuck \& Hamby, 2013; Sanchez, Lambert, \& Cooley-Strickland, 2013) and institutional violence (e.g., law enforcement violence) (Geller, Fagan, Tyler, \& Link, 2014; Legewie \& Fagan, 2018).

The issue is widespread and particularly troublesome in cities. Nearly half of U.S. youth (48\%) were polyvictims (exposed to multiple sources of violence) and $58 \%$ had witnessed violence (Finkelhor et al., 2013). In Chicago, over $70 \%$ of youth exposed to community violence also experienced family violence (Jain, Subramanian, \& Molnar, 2010), and nearly half of 18,000 Chicago public school students surveyed reported being stopped by law enforcement officers (Geller, 2017). In New York City, there were over 200,000 recorded police-initiated stops of youth aged 13 to 15 from 2004 to 2012 (Geller, 2017). Geller links the impact of those police stops to community wellbeing in ways concomitant with literature on exposure to community violence.

Youth exposed to multiple forms of violence are often marginalized in other ways, including economically (Sanchez et al., 2013). Multiple, frequent, and cumulative exposures to violence can affect youth socio-emotional, behavioral, and developmental functioning (Hooven, Nurius, Logan-Greene, \& Thompson, 2012; Jones, 2014). Higher rates and more severe types of violence are linked to post-traumatic stress disorder (Trickey, Siddaway, Meiser-Stedman, Serpell, \& Field, 2012) and worse academic outcomes (Legewie \& Fagan, 2018). 


\section{Youth Civic Engagement}

While community violence is inherently negative, civic engagement involves prosocial behaviors that enrich the broader community and address public issues (e.g., volunteering, voting, attending meetings) (Balsano, 2005; Chung \& Probert, 2011; Cohen \& Chaffee, 2013). Civic engagement can take many forms, such as joining community groups, working with bureaucrats, helping neighbors, or signing petitions (Fitzgerald, 2016); such activities can be grouped more broadly within grassroots activism, civic participation, dialogue across groups, and sociopolitical development (Checkoway \& Aldana, 2013; Hope \& Jagers, 2014). There are also diverse forms of civic activities more relevant today (Zaff, Boyd, Li, Lerner, \& Lerner, 2010), given the changing social, political and technological contexts youth experience (Leventhal \& Brooks-Gunn, 2003). For instance, youth today are less civically engaged via traditional metrics relative to prior generations, but are more likely to volunteer, raise funds for causes, and work on local projects (Flanagan \& Levine, 2010). Youth today also engage civically in previously non-existent arenas (e.g., internet, social media). Civic engagement of all types is important to positive individual development and the functioning of democracy (Flanagan \& Levine, 2010).

Civic engagement is associated with improved youth academic, developmental, and health outcomes (Balsano, 2005; Murphey, Lamonda, Carney, \& Duncan, 2004; Vieno, Nation, Perkins, \& Santinello, 2007). Civic activism can promote well-being and resilience for structurally marginalized youth and their communities (Lerner, 2004), especially when it is responsive to youth's cultural and social contexts (Ginwright \& Cammarota, 2007). Community involvement, especially when it leads to social change, can improve socio-emotional outcomes like sense of control, self-esteem, self-efficacy, and optimism for the future (Amna, 2012; Flanagan \& Levine, 2010; McBride et al., 2006; Rogers, Mediratta, \& Shah, 2012). Civic engagement could also lead to structural changes, like reducing future generations' exposure to community violence. This is the motivating factor behind current movements like Black Lives Matter and \#MeToo.

\section{Setting an Agenda for Research and Practice on Civic Engagement Among Violence- Exposed Youth}

Researchers have focused on the concentration of community violence in cities or on civic engagement among urban youth. Few studies explore how community violence may shape youth civic engagement or how youth civic engagement may affect community violence. To the best of our knowledge, only one study has been published on this topic, finding that exposure 


\section{Civic Engagement Among Violence-Exposed Youth}

to community violence was inversely associated with volunteering in youth who took part in Add Health, a longitudinal adolescent health study (Chen, Propp, \& Lee, 2015).

Efforts to characterize and assess these relationships are inherently complex. For example, ETV is linked with adverse psychosocial outcomes among youth, but social capital, collective efficacy, and non-profit organizations can buffer the effects of ETV (Osofsky, 1995; Sampson et al., 2005). Further, developmental assets (protective factors fundamental for positive youth development (PYD) 1 that are salient to a young person's developmental stage) appear to build resilience among violence-exposed youth (Jain \& Cohen, 2013). We hypothesize that civic engagement may contribute to the development of resilience among youth, and that, through priming young people's agency, civic engagement can contribute to the transformation of their environments. While there may be links between "external" developmental assets, features of PYD, and civic contribution (Lerner \& Lerner, 2011), the mechanisms that underlie these links, and how they manifest for structurally marginalized, violence-exposed youth, are unknown.

In the following section, we apply PYD and resilience lenses to the literature on civic engagement among youth exposed to community violence, and offer directions for future research and practice. Figure 1 visually depicts our findings, which are explained in subsequent sections.

We encourage creating positive, trauma-informed institutions (e.g., schools, community centers, juvenile justice systems) that can support youth across multiple sectors related to civic engagement and violence victimization. We also encourage (a) harnessing the potential of civic engagement programs to mitigate the deleterious effects of exposure to violence, and (b) harnessing the potential of programs designed for violence-exposed youth to encourage civic engagement in efforts that could reduce future community violence.

\footnotetext{
${ }^{1}$ Positive youth development is a conceptualization of adolescence that focuses on the strengths that youth develop, including the Five Cs of competence, confidence, connection, character, and caring (Lerner, Almeriegi, Theokas, \& Lerner, 2005).
} 
Figure 1. Pathways Through Which Exposure to Community Violence May Impact Youth Civic Engagement

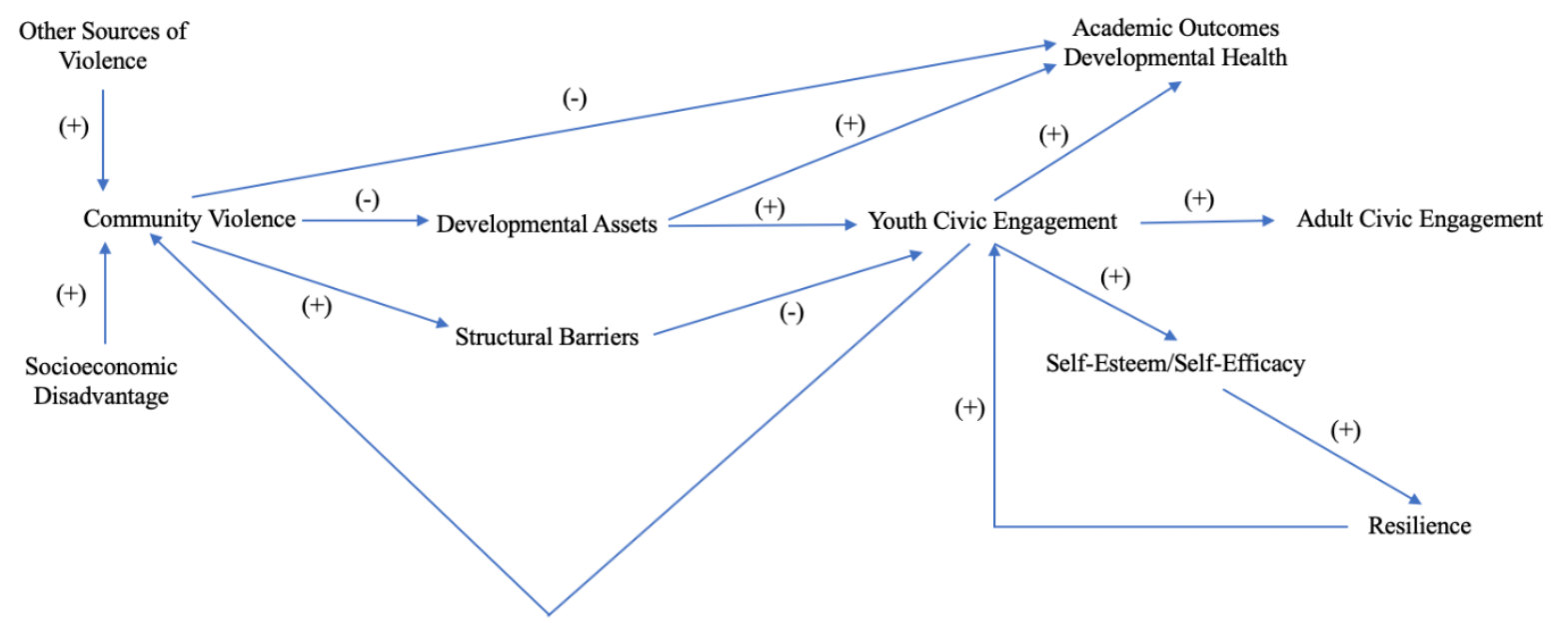

Figure 1 presents a summary of findings from this review of the emerging literature on civic engagement among youth exposed to community violence. These findings situate an understanding of community violence as shaped and compounded by socioeconomic disadvantage, among other forms of institutional violence. They highlight how through pathways of external developmental assets (e.g., collective efficacy) versus structural barriers (e.g., limited transportation), community violence may positively or negatively shape youth civic engagement opportunities and outcomes. Outcomes that have been linked to youth civic engagement include developmental health, self-esteem and self-efficacy, academic success, continued civic engagement into adulthood, social justice, social capital, and community violence, among others. Building from these findings, we offer recommendations for future research as well as implications for policy and practice.

\section{Civic Engagement Within the Context of Resilience Among Violence-Exposed Youth}

\section{Theoretical Basis}

Resilience, a dynamic developmental process, occurs over time within the context of risks (e.g., violence exposure) and encompasses positive outcomes (e.g., civic engagement) (Luthar, 2003). Resilience offers an assets-based approach to considering reactions to community violence. 
In line with our commitment to PYD, we use an assets- and strengths-based approach. We emphasize that most violence-exposed youth, just like their unexposed counterparts, develop into caring, confident, and competent adults through many pathways (Jain, Buka, Subramanian, \& Molnar, 2012) one of which may include civic engagement. In fact, Lerner (2004) suggests that civic engagement is an expression of thriving, an outcome observed within the context of PYD and the process of resilience.

The ecological-transactional (Cicchetti \& Lynch, 1993), developmental assets (Benson, 2002), and phenomenological variant of ecological systems theory (PVEST) (Spencer, 2008) frameworks suggest that violence-exposed youth may cope or recover constructively over time (Jain et al., 2012) with the help of protective factors (e.g., individual agency, community-level opportunities, parental influence) in nested contexts that in turn may shape civic attitudes, beliefs, and behaviors in adolescence and beyond. As we think about potential mechanisms, there are four additional theories that can provide useful insights. Institutional theory suggests that opportunity matters the most (Roy, Tubbs \& Burton, 2004). Cultural theories of generational and socialization influences (Waid \& Frazier, 2003) identify families and cultural institutions as relevant influences on civic engagement. Life-course theories suggest that processes and events over a person's life determine civic participation. Finally, there are resource-based theories like Verba, Schlozman and Brady's (1995) Civic Voluntarism Model. Together, these theories suggest that experiences, information, efficacy, and environments provide the desire, knowledge, and self-assurance to be engaged, and that opportunities and infrastructure for engagement are essential.

To the best of our knowledge, these frameworks have not been used to examine civic participation among violence-exposed youth. Exposure to violence may necessitate youth resiliency, with one pathway being via civic engagement, including collective efficacy to address issues with others, understanding of injustice and justice, and/or strategic thinking and agency. For example, strategic thinking allows youth to use clues from their settings to prepare for possible events and create a work plan for action to reach a desired outcome (Larson \& Angus, 2011). This skill is useful both for navigating community violence and for being civically engaged. 


\section{Civic Development and Intersections With Exposure to Violence}

A certain baseline level of psychosocial development is necessary for civic engagement (Obradović \& Masten, 2007), and civic engagement represents a developmental task beginning in adolescence (Flanagan \& Levine, 2010; Zaff et al., 2010). Adolescence is a particularly important period for civic development (Eckstein, Noack, \& Gniewosz, 2012), and adolescent identity formation is linked with civic engagement (Crocetti, Jahromi, \& Meeus, 2012), but less is known about how adolescents develop civic identities and patterns of civic engagement (Amna, 2012).

Exploring changes in civic engagement during adolescence is particularly important. Youth who are meaningfully engaged in their formative years tend to remain engaged as adults (Conner, 2011; Stewart \& McDermott, 2004), so interventions in adolescence could have long-term individual and societal benefits (Kennedy, 2007). Though adolescents tend to be less civically engaged than older adults, civic engagement increases notably during early adulthood (Flanagan \& Levine, 2010). Emerging adulthood is also a unique transitional time when life trajectories change and enhanced resilience and recovery from childhood exposure to violence often occurs (Compas, Hinden, \& Gerhardt, 1995). Therefore, it is particularly important to study links between youth exposure to violence and civic engagement trajectories within the time frame of adolescence and emerging adulthood.

\section{Inequalities in Civic Engagement and Exposure to Violence}

Opportunities for youth civic engagement are disproportionately distributed by socioeconomic position and race/ethnicity (Flanagan \& Levine, 2010; Ginwright, 2010; Godsay, KawashimaGinsberg, Kiesa, \& Levine, 2012; Rubin \& Hayes, 2010). Structurally marginalized, youth of color are less likely to be civically engaged than their structurally supported, white counterparts (Levinson, 2012; Littenberg-Tobias \& Cohen, 2016; Rogers et al., 2012), but want to be (Rubin, Hayes, \& Benson, 2009). There are several structural impediments (e.g., lack of organized and accessible civic groups, limited time, and limited transportation) to civic engagement in these populations (Rubin \& Hayes, 2010). This may be because youth of color-who are overrepresented in juvenile justice systems, foster care, and have greater exposure to violence-have fewer civic opportunities (Levinson, 2012), face greater systematic barriers to participation (e.g., voter ID laws, transportation policies) (Center for Information and Research on Civic Learning and Engagement (CIRCLE), 2018), and expect their actions will have a minimal impact (Chung \& Probert, 2011). 
However, when opportunities for civic engagement exist, low-income youth are as likely as higher-income youth to participate. Further, when volunteering, low-income youth demonstrate the same or higher levels of civic participation than those who do not volunteer, suggesting that volunteer opportunities may help foster PYD (Spring, Grimm, \& Dietz, 2008). PYD programs, in which violence-exposed youth are sometimes encouraged to participate, should do more to increase civic engagement. For example, Catalano, Berglund, Ryan, Lonczak, \& Hawkins (2002) reviewed 20 PYD programs, none of which reported changes in critical thinking or sociopolitical development (although there were other PYD benefits). In sum, structurally marginalized youth-including those exposed to community violence-want to be engaged, but have fewer opportunities for engagement, engage at different rates, and express civic engagement differently (Ginwright \& Cammarota, 2007). Closing the civic engagement gap must remain a priority (Levinson, 2012; Pope, Stolte, \& Cohen, 2011).

\section{Predictors of Civic Engagement Among Youth Exposed to Community Violence}

Many of those exposed to community violence are also less civically engaged. Importantly, youth exposed to community violence can have varying individual levels of exposures of violence (i.e., duration, frequency, severity, type) and also differences in socioeconomic position, gender, race/ethnicity, neighborhood context, and school setting (Becker, 2013; Kennedy, 2007; Sampson, 2012). Some studies of civic engagement in urban settings (e.g., Godsay et al., 2012; Rubin \& Hayes, 2010) suggest that what civic engagement entails, why people become engaged, and how civic engagement is perceived can vary greatly depending on a youth's home, school, and community contexts.

Similarly, community resilience to violence may differ by levels of collective efficacy, and collective efficacy is also related to individual civic engagement (Sampson, 2012). Levine (2015) presents a theory of action that requires deliberation, collaboration, and civic relationships-all activities that can only occur in a collective space-to achieve ethical and effective civic actions.

\section{Developmental Assets}

Developmental assets are factors that can promote general PYD and child well-being (Scales, Roehlkepartain, \& Shramko, 2017). External developmental assets (i.e., having a caring adult, meaningful opportunities for participation, and high expectations at home, community, and 
school) are salient for the healthy development of all youth, and may offer a window of intervention to increase civic engagement for violence-exposed youth. Developmental assets can improve emotional and behavioral functioning among violence-exposed youth (Jain et al., 2012) and increase civic engagement (Benson, 2007; Sherrod, 2007). Structurally marginalized youth exposed to violence themselves have voiced the importance of having caring adults and meaningful opportunities as a mechanism for civic development (CIRCLE, 2012). Below, we specifically highlight theoretically and empirically supported factors that may be particularly relevant for civic engagement among violence-exposed youth.

\section{Relationship With a Caring Adult}

Having a relationship with a caring adult is associated with improved outcomes for survivors of violence (Jain et al., 2012). Many factors that promote emotional well-being for survivors (e.g., social support) also likely promote civic engagement (Pasque, 2008). Having multiple sources of positive role modeling and support is important for PYD, and especially civic development, because connections with positive adults can provide youth entry into civil society and build social capital (Putnam, 2000). Strong relationships with caring adults benefit all youth (Herrera, DuBois \& Grossman, 2013). It is particularly essential, however, for violence-exposed youth to have opportunities for positive support to help buffer their cumulative disadvantages. Exposure to community violence may be associated with lower civic engagement through a pathway in which youth disengage from community settings they perceive to be hazardous-even if, unbeknownst to them, protective spaces exist. Violence may not have to be severe to impact youth's civic and political efficacy.

\section{Parental Expectations and Support}

Different dimensions of family structure and functioning buffer effects of community violence (Gorman-Smith, Henry, \& Tolan, 2004; Hammack, Richards, Luo, Edlynn, \& Roy, 2004). Strong family connections are associated with increased civic engagement (e.g., voting, volunteering, participating in social actions) (Duke, Skay, Pettingell, \& Borowsky, 2009). Adolescents exposed to parental conflicts who feel that they cannot reduce home conflict levels subsequently experience depressive moods and lower political efficacy (Šerek, Lacinová, \& Macek, 2013), suggesting that youths' experience in their immediate environment can affect how they feel about civil society more broadly. 
Civic Engagement Among Violence-Exposed Youth

The mechanisms for how family factors may influence civic engagement for violence-exposed youth may include increasing access to civic opportunities through connections or networks (inperson and/or online), parental involvement in violence prevention efforts, family members who have also been exposed to violence modeling effective civic engagement themselves, and/or providing a supportive home environment that is conducive to discussing ways to engage. There could potentially also be reverse causality. If family members are victims of violence, that could change the family structure in ways that could also affect civic engagement.

\section{Meaningful Opportunities for Participation}

Having structured opportunities for violence-exposed youth can promote PYD (Flanagan \& Levine, 2010; Jain et al., 2012; Sherrod, 2007) and may also influence their civic engagement. Good civic programs that promote autonomy and authentic engagement can help youth avoid harm and develop strategic thinking and a stronger sense of civic responsibility (Larson \& Angus, 2011; Wood, Larson \& Brown, 2009). Additionally, by providing a setting that empowers youth (Eccles \& Gootman, 2002), this could buffer effects of exposure to violence on civic engagement. In addition to availability and access, how meaningful these opportunities are in engaging and being responsive to the unique needs of violence-exposed youth merits further study. At minimum, this is a chance to leverage ongoing efforts towards anti-bullying. Such programs already exist within many schools, and are viable with little external support. Other programs, including those offered by external partners, provide different avenues.

Various school-based action civics programs offer opportunities for meaningful civic engagement opportunities. Such opportunities are important because schools remain the primary point of contact for most youth and are the best opportunity to provide both exposure to diverse peoples and ideas and the space to deliberate on pressing issues (Parker, 2010). Action civics programs like Generation Citizen (Pope et al., 2011) seek to leverage that exposure to promote youth civic action. Though current research does not examine the role that these programs play in combating community violence, their success in addressing other community issues suggests a hidden potential. These programs could enable youth to organize themselves around addressing community violence during their civic action projects.

\section{Faith-Based Civic Engagement}

Participation in faith-based institutions and/or faith-based youth organizations is associated with increased civic engagement (Zaff, Kawashima-Ginsberg, \& Lin, 2011). Church-based civic action 


\section{Civic Engagement Among Violence-Exposed Youth}

is one of the most prevalent ways low-income communities civically engage (McBride et al., 2006), including adolescent volunteerism through churches (McLeigh, Melton, KimbroughMelton, \& Wallace, 2015). Religiousness also appears to have protective behavioral effects for violence-exposed youth of color (Pearce, Jones, Schwab-Stone, \& Ruchkin, 2003). McBride et al. found that over $60 \%$ of structurally marginalized youth who volunteered also attended church weekly. Faith-based institutions could provide civic programming for violence-exposed youth at a large scale. Thus, we recommend engaging staff from these organizations in larger efforts to support the positive civic development of youth exposed to community violence.

\section{Neighborhood Collective Efficacy and Civic Engagement}

Neighborhood collective efficacy is strongly, inversely associated with community and family violence (Jain et al., 2010; Sampson, 2012). One potential mechanism for this association is that collective efficacy promotes youth social, emotional, and behavioral functioning and facilitates youth's ability to take action on civic issues. Additionally, youth living in communities with high collective efficacy may also have family members who are engaged in civic activities, offering another potential pathway for participation. Violence-exposed youth may also be exposed to caregivers and/or community leaders who experienced violence as youth and are now advocating or organizing for social change. Social learning theory suggests violenceexposed youth may model their own civic behavior after these adults.

A community's social infrastructure also matters. Non-profit organizations may increase access to meaningful civic participation opportunities. A high density of non-profit organizations is linked to collective action (Sampson et al., 2005), community resilience (Morello-Frosch, Brown, Lyson, Cohen, \& Krupa, 2011), and curbing violence (Kennedy, 2007; Sampson et al., 2005). Cohesive, connected communities high in social capital could help structurally marginalized youth build resilience (Leventhal \& Brooks-Gunn, 2003) and otherwise influence positive development (Aber, Gephart, Brooks-Gunn, \& Connell, 2000), including civic engagement (Ginwright, 2010), among violence-exposed youth.

Sampson (2012) and Sampson et al. (2005) argue that social settings can promote collective civic action, emphasizing the importance of access to opportunities for engagement. Given the limited number of civic nonprofits and access to these opportunities for violence-exposed youth, it is even more important to creatively identify places and social institutions such as faith-based institutions, recreational and school-based programs, and peer networks that violence-exposed youth may access and use that could incorporate civic and social justice programming. In turn, 


\section{Civic Engagement Among Violence-Exposed Youth}

through structurally supported engagement at individual and community levels (Zeldin, 2004), youth may become agents in disrupting structural violence and transforming their communities (Lee \& Thomas, 2010), partly through increased social capital (Balsano, 2005).

\section{Future Research Directions}

We propose several directions for future research on civic engagement among youth exposed to community violence. First, researchers should assess whether exposure to community violence is associated with youth civic engagement and if so, if this association is modified by gender, socioeconomic position, race and ethnicity, and/or immigration status. Second, we encourage researchers to use the developmental assets, ecological-transactional, and PVEST frameworks to explore what can disrupt associations between exposure to violence and civic engagement (e.g., age-appropriate developmental assets in communities, families, and/or schools). Third, qualitative and quantitative research should build upon civic engagement and resilience research among structurally marginalized youth and explore links between place-based risk indices (e.g., concentrated disadvantage), community-level protective factors, individual-level exposure to community violence, and civic engagement in adolescence and adulthood.

In addition to studying how exposure to community violence and civic engagement interrelate within youth's lives, we must also assess the impacts of potential interventions. For example, researchers should assess whether interventions to increase civic engagement have a differential impact among violence-exposed youth versus their unexposed counterparts. We hypothesize that some civic engagement interventions may have no differential benefit, but others-in particular, those that take a trauma-informed and strengths-based approach-may be more beneficial for youth exposed to community violence. In addition to studying typical programmatic interventions, we encourage researchers to also explore the impacts of social movements and structural interventions, like Black Lives Matter and \#MeToo.

Finally, we urge researchers to study how current policies and practices may shape community violence and youth civic engagement. For example, evaluations of national policies and programs to promote civic engagement, such as AmeriCorps, YouthBuild, and the Kennedy Act (Flanagan \& Levine, 2010), should assess what populations are being engaged, how, in which neighborhoods, and if exposure to community violence affects civic engagement patterns. While many have focused on individual civic engagement, emerging work on the community and developmental contexts in which violence-exposed youth grow and develop is critical. Future 
researchers should explore how existing individual and community civic engagement initiatives may affect youth exposed to community violence.

\section{Implications for Youth Policy and Practice}

Engaging and empowering violence-exposed youth through initiatives that draw from youth development principles and civic engagement curricula should be central to violence prevention efforts. We recommend developing collaborative, resilience-based, trauma-informed programs and strategies across juvenile justice, education, social services, and health sectors, by providing meaningful opportunities and resources to communities and schools so that youth can take civic action to address causes of community violence.

What should programming that is specifically adapted to increase civic engagement among violence-exposed youth look like? Existing programs that attempt to engage with both exposure to violence and civic engagement may provide guidance. For example, the Civic Engagement Curriculum (Richards et al., 2016), a strengths-based intervention, aims to improve resilience, while the Truth $\mathrm{N}^{\prime}$ Trauma project (Harden et al., 2015) includes participatory action research within a violence prevention intervention. The Civic Engagement Curriculum was designed originally for suburban Midwestern students, but then adapted specifically for African American middle school students in Chicago. The curriculum involved service learning to take action to address local community violence (Richards et al., 2016). The Truth $\mathrm{N}^{\prime}$ Trauma project, also in Chicago, worked with high school students, using a restorative and trauma-based approach to support students doing either action research or a less civically engaged activity (Harden et al., 2015). Community organizers who engage youth and promote youth leadership can leverage youth organizing's growing popularity (Christens \& Kirshner, 2011) as an evidence-based practice for violence prevention (Miao, Umemoto, Gonda, \& Hishinuma, 2011).

Finally, there are programs that focus on either civic engagement or violence prevention that could also integrate the other dimension. For example, school-based action civics programs that focus on guiding students through taking action on a local community issue, like Generation Citizen (Pope et al., 2011), could train classroom teachers on trauma-informed approaches to prepare them to support students interested in tackling issues of community violence. Alternatively, programs like CeaseFire, which seeks to prevent community violence by diverting those at high-risk for committing violence into more positive activities (Webster, Whitehill, Vernick, \& Curriero, 2013), could make civic activism one of those positive activities. Opportunities for structurally marginalized youth to engage in pro-social civic engagement 


\section{Civic Engagement Among Violence-Exposed Youth}

should specifically target youth in areas with high community violence. Further, these efforts should seek to address sociodemographic disparities in civic engagement opportunities.

Ideally, civic engagement programs could help mitigate the negative effects of violence exposure, and violence prevention programs could focus on increasing social support and meaningful opportunities that promote civic engagement. Faith-based and youth development organizations could incorporate developmentally appropriate strategies ${ }^{2}$ and identify opportunities to engage youth (e.g., Beyerlein, Trinitapoli, \& Adler, 2011). More funders should support adapting curricula, programs, and outreach to specifically address the experiences of violence-exposed youth victims and polyvictims. Additionally, collaborations across juvenile justice, schools, community-based organizations, and other partners could help build infrastructure and scaffolding for youth civic experiences.

Promoting youth civic engagement could help address community violence. The ultimate challenge involves integrating youth into their communities as contributing citizens who have agency and capacity in solving problems (i.e., Sirianni, 2009), rather than perceiving them as passive objects of concern (Ginwright, 2007). An assets-based approach provides policymakers and practitioners insights from youth exposed to community violence. Those youth are experts in their lived experiences, can facilitate opportunities for their own civic engagement, and can work together towards the common goal of transforming their shared communities.

\footnotetext{
${ }^{2}$ Developmentally appropriate strategies are approaches tailored to the participants' developmental stage, often using age as a proxy for developmental stage (Eccles et al., 1993).
} 


\section{References}

Aber, J. L., Gephart, M. A., Brooks-Gunn, J., \& Connell, J. P. (2000). Development in context: Implications for studying neighborhood effects. In J. Brooks-Gunn, G. J. Duncan, \& J. L. Aber (Eds.), Neighborhood poverty: Context and consequences for children (pp. 44-61). New York, NY: Russell Sage Foundation.

Amnå, E. (2012). How is civic engagement developed over time? Emerging answers from a multidisciplinary field. Journal of Adolescence, 35(3), 611-627. doi:10.1016/j.adolescence.2012.04.011

Balsano, A. B. (2005). Youth civic engagement in the United States: Understanding and addressing the impact of social impediments on positive youth and community development. Applied Developmental Science, 9(4), 188-201. doi:10.1207/s1532480xads0904_2

Becker, S. (2013). An intersectional analysis of differential opportunity structures for community-based anticrime efforts. Race and Justice, 3(1), 31-57. doi:10.1177/2153368712462409

Benson, P. L. (2002). Adolescent development in social and community context: A program of research. New Directions for Youth Development, 2002(95), 123-148. doi:10.1002/yd.19

Benson, P. L. (2007). Developmental assets: An overview of theory, research, and practice. In R. K. Silbereisen \& R. M. Lerner (Eds.), Approaches to positive youth development (pp. 33-58). London, UK: Sage.

Beyerlein, K., Trinitapoli, J., \& Adler, G. (2011). The effect of religious short-term mission trips on youth civic engagement. Journal for the Scientific Study of Religion, 50(4), 780-795. doi:10.1111/j.1468-5906.2011.01607.x

Black Lives Matter. (2018). Black Lives Matter | About. Retrieved 31 October, 2018 from https://blacklivesmatter.com/about/

Catalano, R. F., Berglund, M. L., Ryan, J. A., Lonczak, H. S., \& Hawkins, J. D. (2002). Positive youth development in the United States: Research findings on evaluations of positive youth development programs. Prevention \& Treatment, 5(1), Article ID 15. doi:10.1037//15223736.5.1.515a

Checkoway, B., \& Aldana, A. (2013). Four forms of youth civic engagement for diverse democracy. Children and Youth Services Review, 35(11), 1894-1899. doi:10.1016/j.childyouth.2013.09.005

Chen, W. Y., Propp, J., \& Lee, Y. (2015). Connection between adolescent's exposure to community violence and future civic engagement behaviors during their young adulthood. Child and Adolescent Social Work Journal, 32(1), 45-55.

Christens, B. D., \& Kirshner, B. (2011). Taking stock of youth organizing: An interdisciplinary perspective. New Directions for Child and Adolescent Development, 2011(134), 27-41. doi:10.1002/cd.309 
Civic Engagement Among Violence-Exposed Youth

Chung, H. L., \& Probert, S. (2011). Civic engagement in relation to outcome expectations among African American young adults. Journal of Applied Developmental Psychology, 32(4), 227-234. doi:10.1016/j.appdev.2011.02.009

Cicchetti, D., \& Lynch, M. (1993). Toward an ecological/transactional model of community violence and child maltreatment: Consequences for children's development. Psychiatry: Interpersonal and Biological Processes, 56, 96-118. doi:10.1080/00332747.1993.11024624

The Center for Information and Research on Civic Learning and Engagement. (2012). Pathways into leadership: A study of YouthBuild graduates. Medford, MA.

The Center for Information and Research on Civic Learning and Engagement) (2018). Why youth don't vote - Differences by race and education. Available online at: https://civicyouth.org/why-youthdont-vote-differences-by-race-and-education/?cat_id=6 (accessed 11 October 2018).

Cohen, A. K., \& Chaffee, B. W. (2013). The relationship between adolescents' civic knowledge, civic attitude, and civic behavior and their self-reported future likelihood of voting. Education, Citizenship, and Social Justice, \&(1), 43-57. doi:10.1177/1746197912456339

Colletta, N. J., and Cullen, M. L. (2000). Violent conflict and the transformation of social capital. Lessons from Cambodia, Rwanda, Guatemala, and Somalia. Washington, DC: The International Bank for Reconstruction and Development.

Compas, B. E., Hinden, B. R., \& Gerhardt, C. A. (1995). Adolescent development: Pathways and processes of risk and resilience. Annual Review of Psychology, 46, 265-293.

doi:10.1146/annurev.ps.46.020195.001405

Conner, J. O. (2011). Youth organizers as young adults: Their commitments and contributions. Journal of Research on Adolescence, 21(4), 923-942. doi:10.1111/j.1532-7795.2011.00766.x

Crocetti, E., Jahromi, P., \& Meeus, W. (2012). Identity and civic engagement in adolescence. Journal of Adolescence, 35(3), 521-532. doi:10.1016/j.adolescence.2011.08.003

Dohrn, B., \& Ayers, W. (2016). Young, gifted, and Black: Black lives matter. In J. Conner \& S. M. Rosen (Eds.), Contemporary youth activism. Advancing social justice in the United States (pp. 79-92). Santa Barbara, CA: Praeger.

Duke, N. N., Skay, C. L., Pettingell, S. L., \& Borowsky, I. W. (2009). From adolescent connections to social capital: Predictors of civic engagement in young adulthood. Journal of Adolescent Health, 44(2), 161-168. doi:10.1016/j.jadohealth.2008.07.007

Eccles, J., \& Gootman, J. A. (Eds.) (2002). Community programs to promote youth development. Washington, DC: National Academy Press.

Eccles, J. S., Midgley, C., Wigfield, A., Buchanan, C. M., Reuman, D., Flanagan, C., \& Mac Iver, D. (1993). Development during adolescence: The impact of stage-environment fit on young adolescents' experiences in schools and in families. American psychologist, 48(2), 90-101. 
Civic Engagement Among Violence-Exposed Youth

Eckstein, K., Noack, P., \& Gniewosz, B. (2012). Attitudes toward political engagement and willingness to participate in politics: Trajectories throughout adolescence. Journal of Adolescence, 35(3), 485495. doi:10.1016/j.adolescence.2011.07.002

Finkelhor, D., Shattuck, A., Turner, H., \& Hamby, S. (2013). Improving the adverse childhood experiences study scale. JAMA Pediatrics, 1671), 70-75. doi:10.1001/jamapediatrics.2013.420

Fitzgerald, J. C. (2016). Pre-planning civic action: An analysis of civic leaders' problem solving strategies. Journal of International Social Studies, 6(2), 58-83. doi:10.1002/ajcp.12103

Flanagan, C., \& Levine, P. (2010). Civic engagement and the transition to adulthood. The Future of Children, 20(1), 159-179.

Friedson, M., \& Sharkey, P. (2015). Violence and neighborhood disadvantage after the crime decline. The Annals of the American Academy of Political and Social Science, 660(1), 341-35. doi:10.1177/0002716215579825

Geller, A. (2017). Policing America's children: Police contact and consequences among teens in Fragile Families. Fragile Families Working Paper WP18-02-FF. Retrieved from https://fragilefamilies.princeton.edu/sites/fragilefamilies/files/wp18-02-ff.pdf

Geller, A., Fagan, J., Tyler, T., \& Link, B. G. (2014). Aggressive policing and the mental health of young urban men. American Journal of Public Health, 104(12), 2321-2327. doi:10.2105/AJPH.2014.302046

Ginwright, S. A. (2007). Black youth activism and the role of critical social capital in black community organizations. American Behavioral Scientist, 51(3), 403-418.

Ginwright, S. A. (2010). Peace out to revolution! Activism among African American youth: An argument for radical healing. Young, 18(1), 77-96. doi:10.1177/110330880901800106

Ginwright, S., \& Cammarota, J. (2007). Youth activism in the urban community: Learning critical civic praxis within community organizations. International Journal of Qualitative Studies in Education, 20(6), 693-710. doi:10.1080/09518390701630833

Godsay, S., Kawashima-Ginsberg, K., Kiesa, A., \& Levine, P. (2012). That's not democracy: How out-ofschool youth engage in civic life and what stands in their way. Medford, MA: The Center for Information \& Research on Civic Learning and Engagement.

Gorman-Smith, D., Henry, D. B., \& Tolan, P. H. (2004). Exposure to community violence and violence perpetration: The protective effects of family functioning. Journal of Clinical Child \& Adolescent Psychology, 33, 439-449. doi:10.1207/s15374424jccp3303_2

Hammack, P. L., Richards, M. H., Luo, Z., Edlynn, E. S., \& Roy, K. (2004). Social support factors as moderators of community violence exposure among inner-city African American young adolescents. Journal of Clinical Child \& Adolescent Psychology, 33(3), 450-462. doi:10.1207/s15374424jccp3303_3 
Journal of Youth Development | http://jyd.pitt.edu/ | Vol. 14 Issue 1 DOI 10.5195/jyd.2019.596

Civic Engagement Among Violence-Exposed Youth

Harden, T., Kenemore, T., Mann, K., Edwards, M., List, C., \& Martinson, K. J. (2015). The truth n'trauma project: Addressing community violence through a youth-led, trauma-informed and restorative framework. Child and Adolescent Social Work Journal, 32(1), 65-79. doi:10.1007/s10560-0140366-0

Herrera, C., DuBois, D. L., \& Grossman, J. B. (2013). The role of risk: Mentoring experiences and outcomes for youth with varying risk profiles. New York, NY: A Public/Private Ventures project distributed by MDRC.

Hope, E. C., \& Jagers, R. J. (2014). The role of sociopolitical attitudes and civic education in the civic engagement of black youth. Journal of Research on Adolescence, 24(3), 460-470. doi:10.1111/jora.12117

Hope, E. C., \& Spencer, M. B. (2017). Civic engagement as an adaptive coping response to conditions of inequality: An application of phenomenological variant of ecological systems theory (PVEST). In N. J. Cabrera \& B. Leyendecker (Eds.), Handbook on positive development of minority children and youth (pp. 421-435). Cham, Switzerland: Springer International.

Hooven, C., Nurius, P. S., Logan-Greene, P., \& Thompson, E. A. (2012). Childhood violence exposure: Cumulative and specific effects on adult mental health. Journal of Family Violence, 276), 511522. doi:10.1007/s10896-012-9438-0

Jain, S., Buka, S. L., Subramanian, S. V., \& Molnar, B. E. (2010). Neighborhood predictors of dating violence victimization and perpetration in young adulthood: A multilevel study. American Journal of Public Health, 100(9), 1737-1744. doi:10.2105/AJPH.2009.169730

Jain, S., Buka, S. L., Subramanian, S. V., \& Molnar, B. E. (2012). Protective factors for youth exposed to violence: Role of developmental assets for building emotional resilience. Journal of Youth Violence and Juvenile Justice, 10(1), 107-129. doi:10.1177/1541204011424735

Jain, S., \& Cohen, A. K. (2013). Behavioral adjustment among youth exposed to community violence: A longitudinal multidisciplinary study of family, peer and neighborhood-level protective factors. Prevention Science, 14(6), 606-617. doi:10.1007/s11121-012-0344-8.

Johnson, L. T., \& Kane, R. J. (2018). Deserts of disadvantage: the diffuse effects of structural disadvantage on violence in urban communities. Crime \& Delinquency, 64(2), 143-165. doi: $10.1177 / 0011128716682228$

Jones, N., (2014). "The regular routine": Proactive policing and adolescent development among young, poor Black men. New Directions for Child and Adolescent Development, 2014(143), 33-54. doi:10.1002/cad.20053

Kahne, J., Hodgin, E., \& Eidman-Aadahl, E. (2016). Redesigning civic education for the digital age: Participatory politics and the pursuit of democratic engagement. Theory \& Research in Social Education, 44(1), 1-35. doi:10.1080/00933104.2015.1132646 
Journal of Youth Development | http://jyd.pitt.edu/ | Vol. 14 Issue 1 DOI 10.5195/jyd.2019.596

Civic Engagement Among Violence-Exposed Youth

Kennedy, A. C. (2007). An ecological approach to examining cumulative violence exposure among urban, African American adolescents. Child and Adolescent Social Work Journal, 25(1), 25-41. doi:10.1007/s10560-007-0110-0

Krug, E. G., Mercy, J. A., Dahlberg, L. L., \& Zwi, A. B. (2002). The world report on violence and health. The Lancet, 360(9339), 1083-1088.

Larson, R. W. \& Angus, R. M. (2011). Adolescents' development of skills for agency in youth programs: Learning to think strategically. Child Development, 82(1), 277-294. doi:10.1111/j.14678624.2010.01555.x

Lee, M. R., \& Thomas, S. A. (2010). Civic community, population change, and violent crime in rural communities. Journal of Research in Crime and Delinquency, 4Л1), 118-147.

Legewie, J., \& Fagan, J. (2018). Aggressive policing and the educational performance of minority youth. doi:10.31235/osf.io/rdchf

Lerner, R. M. (2004). Liberty: Thriving and civic engagement among America's youth. Thousand Oaks, CA: Sage.

Lerner, R. M., Almerigi, J. B., Theokas, C., \& Lerner, J. V. (2005). Positive youth development a view of the issues. The Journal of Early Adolescence, 25(1), 10-16. doi:10.1177/0272431604273211

Lerner, R. M., \& Lerner, J. V. (2011). The positive development of youth: Report of the findings from the first seven years of the 4-H Study of Positive Youth Development. Medford, MA: Institute for Applied Research in Youth Development, Tufts University.

Leventhal, T., \& Brooks-Gunn, J. (2003). Children and youth in neighborhood contexts. Current Directions in Psychological Science, 12(1), 27-31. doi:10.1111/1467-8721.01216

Levine, P. (2015). We are the ones we have been waiting for. New York, NY: Oxford University Press. Levinson, M. (2012). No citizen left behind. Cambridge, MA: Harvard University Press.

Littenberg-Tobias, J., \& Cohen, A. K. (2016). Diverging paths: Understanding racial differences in civic engagement among White, African American, and Latina/o adolescents using structural equation modeling. American Journal of Community Psychology, 57(1-2), 102-117. doi:10.1002/ajcp.12027

Luthar, S. S. (Ed.). (2003). Resilience and vulnerability. Cambridge University Press.

McBride, A. M., Sherraden, M. S., \& Pritzker, S. (2006). Civic engagement among low-income and lowwealth families: In their words. Family Relations, 55(2), 152-162. doi:10.1111/j.17413729.2006.00366.x

McLeigh, J. D., Melton, G. B., Kimbrough-Melton, R., \& Wallace, N. (2015). How can Strong Communities transform community norms and structures to promote children's safety and well-being? [White paper.\} Retrieved June 30, 2017 from Upbring: https://www.upbring.org/wpcontent/uploads/2015/08/white-paper-strong-communities.pdf. 
Miao, T.-A., Umemoto, K., Gonda, D., \& Hishinuma, E. S. (2011). Essential elements for community engagement in evidence-based youth violence prevention. American Journal of Community Psychology, 48(1-2), 120-132. doi:10.1007/s10464-010-9418-6

Morello-Frosch, R., Brown, P., Lyson, M., Cohen, A., \& Krupa, K. (2011). Community voice, vision, and resilience in post-hurricane Katrina recovery. Environmental Justice, 4(1), 71-80. doi:10.1089/env.2010.0029

Murphey, D. A., Lamonda, K. H., Carney, J. K., \& Duncan, P. (2004). Relationships of a brief measure of youth assets to health-promoting and risk behaviors. Journal of Adolescent Health, 34(3), 184191. doi:10.1016/j.jadohealth.2003.05.004

Obradović, J., \& Masten, A. S. (2007). Developmental antecedents of young adult civic engagement. Applied Developmental Science, 11(1), 2-19. doi:10.1080/10888690709336720

Osofsky, J. D. (1995). The effect of exposure to violence on young children. American Psychologist, 50(9), 782. doi:10.1037/0003-066X.50.9.782

Parker, W. C. (2010). Listening to strangers: Classroom discussion in democratic education. Teachers College Record, 112(11), 2815-2832.

Pasque, P.A. (2008). Bridging civic engagement and mental health: Proceedings from the National Symposium for Civic Engagement and Mental Health. Washington DC: Charles Engelhard Foundation and Association of American Colleges and Universities.

Pearce, M. J., Jones, S. M., Schwab-Stone, M. E., \& Ruchkin, V. (2003). The protective effects of religiousness and parent involvement on the development of conduct problems among youth exposed to violence. Child Development, 74(6), 1682-1696.

Pope, A., Cohen, A. K., Duarte, C. Making civic engagement go viral: Applying social epidemiology principles to civic education. Journal of Public Affairs. 2018; Epub ahead of print, e1857. doi:10.1002/pa.1857

Pope, A., Stolte, L., \& Cohen, A. K. (2011). Closing the civic engagement gap: The potential of action civics. Social Education, 75(5), 267-270.

Putnam, R. D. (2000). Bowling Alone. New York: Simon \& Schuster.

Richards, M., Romero, E., Deane, K., Carey, D., Zakaryan, A., Quimby, D., . . \& Patel, N. (2016). Civic engagement curriculum: A strengths-based intervention serving African American youth in a context of toxic stress. Journal of Child \& Adolescent Trauma, 9(1), 81-93. doi:10.1007/s40653015-0062-z

Rogers, J., Mediratta, K., \& Shah, S. (2012). Building power, learning democracy: Youth organizing as a site of civic development. Review of Research in Education, 36(1), 43-66.

Roy, K. M., Tubbs, C. Y., \& Burton, L. M. (2004). Don't have no time: Daily rhythms and the organization of time for low-income families. Family Relations, 53(2), 168-178. doi:10.1111/j.00222445.2004.00007.x 
Civic Engagement Among Violence-Exposed Youth

Rubin, B. C., Hayes, B., \& Benson, K. (2009). "It's the worst place to live": Urban youth and the challenge of school-based civic learning. Theory Into Practice, 48(3), 213-221.

doi:10.1080/00405840902997436

Rubin, B. C., \& Hayes, B. (2010). "No Backpacks" versus "Drugs and Murder": The promise and complexity of youth civic action research. Harvard Educational Review, 80(3), 352-379. doi:10.17763/haer.80.3.p709264772m6186g

Ruck, M. D., Keating, D. P., Saewyc, E. M., Earls, F., \& Ben-Arieh, A. (2016). The United Nations Convention on the Rights of the Child: Its relevance for adolescents. Journal of Adolescence, 26(1), 16-29. doi:10.1111/jora.12172

Sampson, R. J. (2012). Great American city: Chicago and the enduring neighborhood effect. Chicago, IL: University of Chicago Press.

Sampson, R. J., McAdam, D., MacIndoe, H., \& Weffer Elizondo, S. (2005). Civil society reconsidered: The durable nature and community structure of collective civic action. American Journal of Sociology, 111(3), 673-714. doi:10.1086/497351

Sanchez, Y. M., Lambert, S. F., \& Cooley-Strickland, M. (2013). Adverse life events, coping and internalizing and externalizing behaviors in urban African American youth. Journal of Child and Family Studies, 22(1), 38-47. doi:10.1007/s10826-012-9590-4

Scales, P. C., Roehlkepartain, E. C., \& Shramko, M. (2017). Aligning youth development theory, measurement, and practice across cultures and contexts: Lessons from use of the Developmental Assets Profile. Child Indicators Research, 10(4), 1145-1178. doi:10.1007/s12187-016-9395-x

Šerek, J., Lacinová, L, Macek, P. (2013). Does family experience influence political beliefs? Relation between interparental conflict perceptions and political efficacy in late adolescence. Journal of Adolescence, 35(3), 577-586. doi:10.1016/j.adolescence.2011.10.001

Sherrod, L. (2007). Civic engagement as an expression of positive youth development. In R. Silbereisen, \& R. Lerner (Eds.), Approaches to positive youth development. London: Sage.

Sirianni, C. (2009). Investing in democracy: Engaging in citizens in collaborative governance. Washington, DC: The Brookings Institution.

Spencer, M. B. (2008). Phenomenology and ecological systems theory: Development of diverse groups. In W. Damon \& R. M. Lerner (Eds.) Handbook of child psychology: Theoretical models of human development (pp. 829-893). Hoboken, NJ: Wiley.

Spring, K., Dietz, N., \& Grimm, R. J. (2007). Leveling the path to participation: Volunteering and civic engagement among youth from disadvantaged circumstances. Washington, DC: Corporation for National and Community Service.

Spring, K., Grimm, R. J., \& Dietz, N. (2008). Community Service and Service-Learning in America's Schools. Washington, DC: Corporation for National and Community Service. 


\section{Civic Engagement Among Violence-Exposed Youth}

Stewart, A. J., \& McDermott, C. (2004). Civic engagement, political identity, and generation in developmental context. Research in Human Development, 1(3), 189-203. doi:10.1207/s15427617rhd0103_4

Trickey, D., Siddaway, A. P., Meiser-Stedman, R., Serpell, L., \& Field, A. P. (2012). A meta-analysis of risk factors for post-traumatic stress disorder in children and adolescents. Clinical Psychology Review, 32(2), 122-138. doi:10.1016/j.cpr.2011.12.001

Verba, S., Schlozman, K. L., \& Brady, H. (1995). Voice and Equality: Civic Voluntarism in American Politics. Cambridge, MA: Harvard University Press.

Vieno, A., Nation, M., Perkins, D. D., \& Santinello, M. (2007). Civic participation and the development of adolescent behavior problems. Journal of Community Psychology, 35(6), 761-777. doi:10.1002/jcop.20177

Wade, R., Jr., Shea, J. A., Rubin, D., \& Wood, J. (2014). Adverse childhood experiences of low-income urban youth. Pediatrics, 134(1), e13-e20.

Webster, D. W., Whitehill, J. M., Vernick, J. S., \& Curriero, F. C. (2013). Effects of Baltimore's Safe Streets Program on gun violence: A replication of Chicago's CeaseFire Program. Journal of Urban Health, 90(1), 27-40.

Waid, L. D., \& Frazier, L. D. (2003). Cultural differences in possible selves during later life. Journal of Aging Studies, 17(3), 251-268. doi:10.1016/S0890-4065(03)00031-8

Wood, D., Larson, R. W., \& Brown, J. (2009). How adolescents come to see themselves as more responsible through participation in youth programs. Child Development, 80(1), 295-309. doi:10.1111/j.1467-8624.2008.01260.x

Zaff, J., Boyd, M., Li, Y., Lerner, J. V., \& Lerner, R. M. (2010). Active and engaged citizenship: Multigroup and longitudinal factorial analysis of an integrated construct of civic engagement. Journal of Youth and Adolescence, 39(7), 736-750. doi:10.1007/s10964-010-9541-6

Zaff, J. F., Kawashima-Ginsberg, K., \& Lin, E. S. (2011). Advances in civic engagement research: issues of civic measures and civic context. Advances in Child Development \& Behavior, 41, 273-308. doi:10.1016/B978-0-12-386492-5.00011-7

Zeldin, S. (2004). Preventing youth violence through the promotion of community engagement and membership. Journal of Community Psychology, 32(5), 623-641. doi:10.1002/jcop.20023

Zimmerman, G. M., \& Messner, S. F. (2013). Individual, family background, and contextual explanations of racial and ethnic disparities in youths' exposure to violence. American Journal of Public Health, 103(3), 435-442. doi:10.2105/AJPH.2012.300931 